\title{
A New Ligand for Europium(III) That Forms a Stable Fluorescent Complex in Aqueous Solution
}

\author{
Daikichi Horiguchi, ${ }^{a}$ Yoshiki Katayama, ${ }^{a}$ Kazumi Sasamoto, ${ }^{* a}$ Hideyuki Terasawa, ${ }^{b}$ Naofumi Sato, ${ }^{b}$ Hiroshi \\ MOCHIZUKI $^{b}$ and Yosuke OHKURA ${ }^{c}$
}

Dojindo Laboratories, ${ }^{a}$ Tabaru 2025-5, Mashiki-machi, Kumamoto 861-22, Japan, Biosciences Research Laboratory, Mochida Pharmaceutical Co., Ltd., Kamiya 1-1-1, Kita-ku, Tokyo 115, Japan and Faculty of Pharmaceutical Sciences, Kyushu University 62,' Higashi-ku, Fukuoka 812, Japan. Received June 22, 1992

A new macrocyclic ligand for $\mathrm{Eu}^{3+}, 24,30-$ diphenyl-8,19-(1,21:4,6:10,12:15,17-tetraetheno-8,9,19,20-tetrahydro$7 H, 18 H$-dibenzo $[b, k][1,4,7,10,13,16]$ hexaazacyclooctadecine)diacetic acid $(1)$, was synthesized and its fluorescence characteristics were examined, particularly to compare with 4,7-bis(chlorosulfophenyl)-1,10-phenanthroline-2,9dicarboxylic acid (BCPDA) that has proved to be useful as a label in time-resolved fluoroimmunoassays. The complex of macrocycle 1 with $\mathrm{Eu}^{3+}$ was found to have a higher fluorescence intensity as well as a longer fluorescence lifetime than that of BCPDA.

Keywords phenanthrolinophane derivative; macrocycle; europium chelator; stable fluorescence; aqueous medium

A number of analytical methods alternative to radioimmunoassay (RIA) have been extensively explored for immunological assays since RIA has several drawbacks as health hazards and the need for special disposal. Among various non-RIA techniques, time-resolved fluoroimmunoassay (TR-FIA) using $\mathrm{Eu}^{3+}$ complex as a label is gaining much attention because of its high sensitivity equivalent to RIA. TR-FIA is based on the unique spectroscopic properties of $\mathrm{Eu}^{3+}$ chelates of long fluorescence lifetimes $(600-1000 \mu \mathrm{s})$ and large Stokes shifts $(c a .290 \mathrm{~nm})$ with an emission wavelength at or near $615 \mathrm{~nm} .^{1,2)}$ Two types of approaches have been exploited: i) One is by Hemmilä and co-workers, ${ }^{1)}$ in which isothiocyanatophenylethylenediaminetetraacetic acid (isothiocyanatophenyl-EDTA) is utilized to bridge an antibody and $\mathrm{Eu}^{3+}$. Although the method using this label has been used successfully, it suffers from the limitation that $\mathrm{Eu}^{3+}$ must be released by lowering $\mathrm{pH}$ from the nonfluorescent $\mathrm{Eu}^{3+}$-EDTA complex in order to be re-complexed by a second chelator of $\beta$-diketone type, 2-naphthoyltrifluoroacetone (NTFA), in a micellar solution composed of Triton X-100 and the synergistic agent tri- $n$-octylphosphine oxide (TOPO) to produce a higher fluorescence. It therefore requires an extra step to the procedure and, as a result, is vulnerable to contamination. ii) The second approach, proposed by Diamandis and co-workers, ${ }^{2,3)}$ is more straightforward in the sense that it allows a direct quantification of $\mathrm{Eu}^{3+}$ in an aqueous solution after the immunoreaction using a chelator, 4,7-bis(chlorosulfophenyl)-1,10-phenanthroline-2,9-dicarboxylic acid (BCPDA). BCPDA forms a stable fluorescent complex with $\mathrm{Eu}^{3+}$ with two heteroaromatic nitrogens and two carboxy groups as the coordination sites, and its fluorescence is insensitive to aqueous quenching. The fluorescence intensity, however, is sensitive to the molar ratio of $\mathrm{Eu}^{3+} / \mathrm{BCPDA}$ of the complex when the ratio is smaller than 1.0. A complex formation of $\mathrm{Eu}^{3+}$ with more than two molecules of BCPDA, which is unlikely in a labeled form, is suggested depending on the molar ratio. ${ }^{3)}$

In an effort to circumvent these disadvantages, we synthesized a new macrocyclic chelator (1, Chart 1) that was designed to form a stable $1: 1$ complex with $\mathrm{Eu}^{3+}$ exhibiting a notable emission in aqueous solution. We wish to describe herein the synthesis and the fluorescence characteristics of macrocycle $\mathbf{1}$, particularly in comparison with BCPDA.

\section{Experimental}

Europium chloride hexahydrate $\left(\mathrm{EuCl}_{3} \cdot 6 \mathrm{H}_{2} \mathrm{O}, 99.99 \%\right)$, samarium chloride hexahydrate $\left(\mathrm{SmCl}_{3} \cdot 6 \mathrm{H}_{2} \mathrm{O},>99.99 \%\right)$ and terbium chloride hexahydrate $\left(\mathrm{TbCl}_{3} \cdot 6 \mathrm{H}_{2} \mathrm{O}, 99.999 \%\right)$ were obtained from Aldrich (Milwaukee, WI, U.S.A.) and were used as purchased. BCPDA was prepared according to the method described by Evangelista et al. ${ }^{3)} \mathrm{A}$ stock

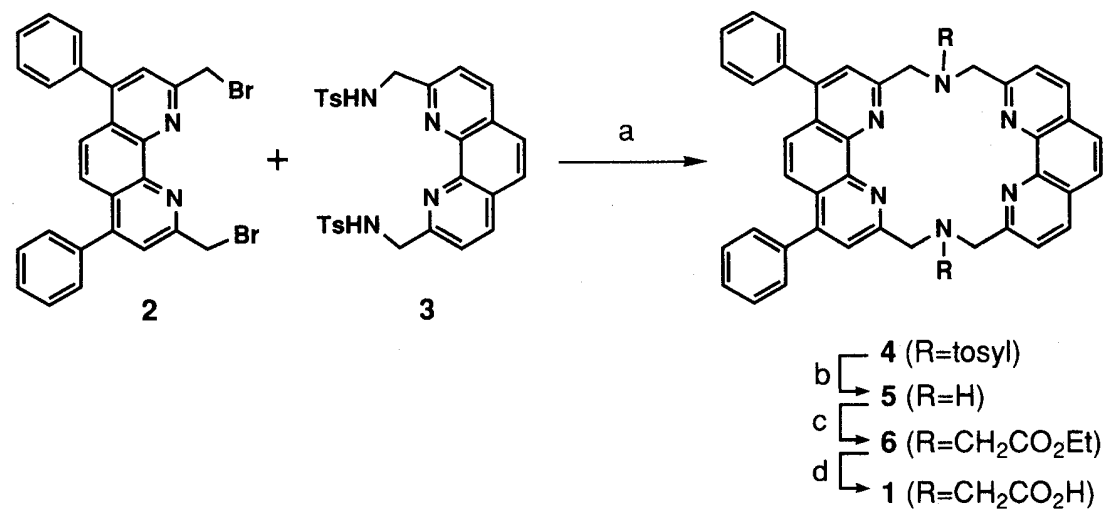

reagents and conditions: (a) $\mathrm{K}_{2} \mathrm{CO}_{3}, \mathrm{DMF}, 50^{\circ} \mathrm{C}$; (b) $\mathrm{HOAc}, \mathrm{H}_{2} \mathrm{SO}_{4}, 100^{\circ} \mathrm{C}$;

(c) ethyl bromoacetate, $\mathrm{K}_{2} \mathrm{CO}_{3}, \mathrm{DMF}, 50^{\circ} \mathrm{C}$; (d) $\mathrm{KOH}, \mathrm{EtOH}$, reflux

Chart 1. Synthetic Route to Macrocycle 1 
solution of macrocycle 1 was prepared as $1 \times 10^{-4} \mathrm{M}$ aqueous solution. ${ }^{1} \mathrm{H}$ - and ${ }^{13} \mathrm{C}$-nuclear magnetic resonance (NMR) spectra were measured on a Bruker AC-200P operating at 200 and $50 \mathrm{MHz}$, respectively, with tetramethylsilane as an internal standard. The splitting patterns were designated as follows: $\mathrm{s}$, singlet; $\mathrm{d}$, doublet; $\mathrm{t}$, triplet; $\mathrm{q}$, quartet; $\mathrm{m}$, multiplet; br, broad. Fluorescence spectra were recorded on a Hitachi 650-60 spectrometer. Time-resolved fluorescence measurements were performed on an Arcus 1230 fluorometer (LKB Wallac, Turku, Finland). IR spectra were taken in $\mathrm{KBr}$ disks on a Hitachi 270-30. Fast atom bombardment mass spectra (FAB-MS) were measured on a JEOL JMS-AX $505 \mathrm{~W}$. Uncorrected melting points were obtained on a Yamato MP-21 melting point apparatus.

4,7-Diphenyl-2,9-bis(bromomethyl)-1,10-phenathroline (2) Dibromide 2 was prepared by the method reported by Chandler et al. ${ }^{4}$ )

2,9-Bis( $p$-toluenesulfonamidomethyl)-1,10-phenanthroline (3) To a stirred solution of 2,9-bis(aminoethyl)-1,10-phenanthroline diperchlorate ${ }^{4}$ ) $(2.2 \mathrm{~g}, 5.0 \mathrm{mmol})$ in pyridine $(20 \mathrm{ml})$ was added $p$-toluenesulfonyl chloride $(2.3 \mathrm{~g}, 12.0 \mathrm{mmol})$ at $0^{\circ} \mathrm{C}$, and the stirring was continued for $3 \mathrm{~h}$ at $22^{\circ} \mathrm{C}$. Water $(100 \mathrm{ml})$ was added and the reaction mixture was partitioned between chloroform and water. The chloroform layer was dried $\left(\mathrm{MgSO}_{4}\right)$ and concentrated to give a colored residue, which was chromatographed on silica gel ( $1 \%$ methanol in chloroform) to afford $1.1 \mathrm{~g}(40 \%)$ of ditosylate 3 as a white powder. $\mathrm{mp} 114^{\circ} \mathrm{C}\left(\mathrm{dec}\right.$ ). IR $\left(\mathrm{cm}^{-1}\right)$ : $3270(\mathrm{NH}), 3070$ (Ar), $2940\left(\mathrm{CH}_{3}\right), 2870\left(\mathrm{CH}_{3}\right), 1630$ (Ar), 1600 (Ar), 1540 (Ar), $1330\left(\mathrm{SO}_{2}\right)$, $1160\left(\mathrm{SO}_{2}\right) .{ }^{1} \mathrm{H}-\mathrm{NMR}\left(\mathrm{CDCl}_{3}\right) \delta: 2.28\left(6 \mathrm{H}, \mathrm{s}, \mathrm{CH}_{3}\right), 4.57(4 \mathrm{H}, \mathrm{d}, J=6.0 \mathrm{~Hz}$, $\left.\mathrm{CH}_{2}\right), 6.67(2 \mathrm{H}, \mathrm{t}, J=6.0 \mathrm{~Hz}, \mathrm{NH}), 7.15(2 \mathrm{H}, \mathrm{d}, J=8.3 \mathrm{~Hz}, \mathrm{Ar}), 7.62(2 \mathrm{H}$, $\mathrm{d}, J=8.3 \mathrm{~Hz}, \mathrm{Ar}), 7.77(6 \mathrm{H}, \mathrm{m}, \mathrm{Ar}), 8.19(2 \mathrm{H}, \mathrm{d}, J=8.3 \mathrm{~Hz}, \mathrm{Ar})$. FAB-MS $m / z: 547(\mathrm{M}+\mathrm{H})^{+}$

24,30-Diphenyl-8,19-bis( $p$-toluenesulfonyl)-1,21:4,6:10,12:15,17-tetraetheno-8,9,19,20-tetrahydro- $7 \mathrm{H}, 18 \mathrm{H}$-dibenzo $[b, k][1,4,7,10,13,16]$ hexaazacyclooctadecine (4) A mixture of dibromide $2(520 \mathrm{mg}, 1.0 \mathrm{mmol})$, ditosylate $3(550 \mathrm{mg}, 1.0 \mathrm{mmol})$ and potassium carbonate $(2.0 \mathrm{~g}, 14.5$ mmol) in $N, N$-dimethylformamide (DMF, $20 \mathrm{ml}$ ) was stirred at $22^{\circ} \mathrm{C}$ for $12 \mathrm{~h}$, and the reaction mixture was filtered. The addition of water $(100 \mathrm{ml})$ resulted in precipitation of the product, which was washed with methanol and dried in vacuo to yield $820 \mathrm{mg}(91 \%)$ of tosylate 4 as an off-white powder. mp $154^{\circ} \mathrm{C}$ (dec.). IR ( $\left.\mathrm{cm}^{-1}\right)$ : $3040(\mathrm{Ar}), 2940\left(\mathrm{CH}_{3}\right), 2870\left(\mathrm{CH}_{3}\right)$, 1630 (Ar), $1600(\mathrm{Ar}), 1540(\mathrm{Ar}), 1350\left(\mathrm{SO}_{2}\right), 1160\left(\mathrm{SO}_{2}\right) .{ }^{1} \mathrm{H}-\mathrm{NMR}$ $\left(\mathrm{CDCl}_{3}\right) \delta: 2.52\left(6 \mathrm{H}, \mathrm{s}, \mathrm{CH}_{3}\right), 4.73\left(4 \mathrm{H}\right.$, br s, $\left.\mathrm{CH}_{2}\right), 5.37\left(4 \mathrm{H}\right.$, br s, $\left.\mathrm{CH}_{2}\right)$, $7.25-7.90(28 \mathrm{H}, \mathrm{m}, \mathrm{Ar}) .{ }^{13} \mathrm{C}-\mathrm{NMR}\left(\mathrm{CDCl}_{3}\right) \delta: 21.61\left(\mathrm{CH}_{3}\right), 56.98\left(\mathrm{CH}_{2}\right)$, $122.90-156.80$ (Ar). FAB-MS $m / z: 903(\mathrm{M}+\mathrm{H})^{+}, 925(\mathrm{M}+\mathrm{Na})^{+}$

24,30-Diphenyl-1,21:4,6:10,12:15,17-tetraetheno-8,9,19,20-tetrahydro$7 H, 18 H$-dibenzo $[b, k][1,4,7,10,13,16]$ hexaazacyclooctadecine (5) A solution of tosylate $4(770 \mathrm{mg}, 0.85 \mathrm{mmol})$ in acetic acid $(4 \mathrm{ml})$ and sulfuric acid $(6 \mathrm{ml})$ was heated at $120^{\circ} \mathrm{C}$ for $10 \mathrm{~h}$, and poured onto ice water $(10 \mathrm{ml})$. Formed precipitates were collected and dried in vacuo to furnish $550 \mathrm{mg}$ $(82 \%)$ of amine 5 as a salt of equivalent sulfuric acid. $\mathrm{mp} 225^{\circ} \mathrm{C}$ (dec.). IR ( $\left.\mathrm{cm}^{-1}\right)$ : 3050 (Ar), $2950\left(\mathrm{CH}_{2}\right), 2850-2500\left(\mathrm{NH}_{2}\right), 1630$ (Ar), 1600 (Ar), 1520 (Ar), $1120(\mathrm{CN}) .{ }^{1} \mathrm{H}-\mathrm{NMR}\left(\mathrm{DMSO}-d_{6}\right) \delta: 4.62\left(8 \mathrm{H}, \mathrm{s}, \mathrm{CH}_{2}\right)$, $7.61(10 \mathrm{H}, \mathrm{s}, \mathrm{Ar}), 7.78(6 \mathrm{H}, \mathrm{d}, J=8.3 \mathrm{~Hz}, \mathrm{Ar}), 8.00(2 \mathrm{H}, \mathrm{s}, \mathrm{Ar}), 8.59(2 \mathrm{H}$, $\mathrm{d}, J=8.2 \mathrm{~Hz}, \mathrm{Ar}$ ). ${ }^{13} \mathrm{C}-\mathrm{NMR}$ (DMSO- $\left.d_{6}\right) \delta: 51.03\left(\mathrm{CH}_{2}\right), 122.82-152.58$ (Ar). FAB-MS $m / z: 594(\mathrm{M}+\mathrm{H})^{+}, 616(\mathrm{M}+\mathrm{Na})^{+}$

24,30-Diphenyl-8,19-[1,21:4,6:10,12:15,17-tetraetheno-8,9,19,20tetrahydro- $7 \mathrm{H}, 18 \mathrm{H}$-dibenzo $[b, k][1,4,7,10,13,16]$ hexaazacyclooctadecine)diacetic Acid Ethyl Ester (6) A mixture of amine 5 (500 $\mathrm{mg}, 0.84 \mathrm{mmol}$ ), ethyl bromoacetate $(2 \mathrm{ml}, 18.0 \mathrm{mmol})$ and potassium carbonate $(2 \mathrm{~g}$, $14.5 \mathrm{mmol})$ in DMF $(20 \mathrm{ml})$ was stirred at $22^{\circ} \mathrm{C}$ for $12 \mathrm{~h}$. The reaction mixture was filtered and the filtrate was concentrated. Diethyl ether $(10 \mathrm{ml})$ was added to an oily residue to form precipitates which were recrystallized from ethanol, yielding $170 \mathrm{mg}(33 \%)$ of ester 6 as a white powder. mp $194-201^{\circ} \mathrm{C}$ (dec.). IR (cm $\left.{ }^{-1}\right): 3070(\mathrm{Ar}), 3000\left(\mathrm{CH}_{2}\right), 2940\left(\mathrm{CH}_{2}\right), 2860$ $\left(\mathrm{CH}_{2}\right), 1740(\mathrm{C}=\mathrm{O}), 1630(\mathrm{Ar}), 1600(\mathrm{Ar}), 1580(\mathrm{Ar}), 1210(\mathrm{C}-\mathrm{O}-\mathrm{C})$. ${ }^{1} \mathrm{H}-\mathrm{NMR}\left(\mathrm{CDCl}_{3}\right) \delta: 1.26\left(6 \mathrm{H}, \mathrm{t}, J=7.1 \mathrm{~Hz}, \mathrm{CH}_{3}\right), 3.90\left(4 \mathrm{H}, \mathrm{s}, \mathrm{CH}_{2} \mathrm{CO}\right)$, $4.18\left(4 \mathrm{H}, \mathrm{q}, J=7.1 \mathrm{~Hz}, \mathrm{CH}_{2}\right), 4.46\left(8 \mathrm{H}, \mathrm{s}, \mathrm{CH}_{2} \mathrm{~N}\right), 7.50(10 \mathrm{H}, \mathrm{s}, \mathrm{Ar}), 7.58$ $(2 \mathrm{H}, \mathrm{s}, \mathrm{Ar}), 7.71(2 \mathrm{H}, \mathrm{d}, J=8.3 \mathrm{~Hz}, \mathrm{Ar}), 7.82(4 \mathrm{H}, \mathrm{s}, \mathrm{Ar}), 8.33(2 \mathrm{H}, \mathrm{d}$, $J=8.2 \mathrm{~Hz}, \mathrm{Ar}) .{ }^{13} \mathrm{C}-\mathrm{NMR}\left(\mathrm{CDCl}_{3}\right) \delta: 14.09\left(\mathrm{CH}_{3}\right), 59.01\left(\mathrm{CH}_{2} \mathrm{~N}\right), 61.00$ $\left(\mathrm{CH}_{2}\right), 64.00\left(\mathrm{CH}_{2} \mathrm{CO}\right), 123.67-158.34(\mathrm{Ar}), 172.67(\mathrm{CO})$. FAB-MS $m / z$ : $805(\mathrm{M}+\mathrm{K})^{+}$

24,30-Diphenyl-8,19-(1,21:4,6:10,12:15,17-tetraetheno-8,9,19,20tetrahydro- $7 H, 18 H$-dibenzo $[b, k][1,4,7,10,13,16]$ hexaazacyclooctadecine)diacetic Acid (1) A solution of ester $6(150 \mathrm{mg}, 0.20 \mathrm{mmol})$ and potassium hydroxide $(200 \mathrm{mg}, 3.5 \mathrm{mmol})$ in ethanol $(20 \mathrm{ml})$ was refluxed for $2 \mathrm{~h}$. The solvent was stripped off to leave an oily residue to which water $(20 \mathrm{ml})$ was added to prompt crystallization. A formed solid was collected, washed with water and dried in vacuo to furnish $110 \mathrm{mg}(70 \%)$ of acid 1 as an off-white powder. $\mathrm{mp} 170^{\circ} \mathrm{C}$ (dec.). IR $\left(\mathrm{cm}^{-1}\right)$ : $3400(\mathrm{OH}), 3060(\mathrm{Ar})$, $2960\left(\mathrm{CH}_{2}\right), 2920\left(\mathrm{CH}_{2}\right), 2850\left(\mathrm{CH}_{2}\right), 1600\left(\mathrm{CO}_{2}\right), 1400\left(\mathrm{CO}_{2}\right) .{ }^{1} \mathrm{H}-\mathrm{NMR}$ $\left(\mathrm{CDCl}_{3}\right) \delta: 3.47\left(4 \mathrm{H}, \mathrm{s}, \mathrm{CH}_{2} \mathrm{CO}\right), 4.26\left(4 \mathrm{H}, \mathrm{m}, \mathrm{CH}_{2}\right), 4.42\left(4 \mathrm{H}, \mathrm{m}, \mathrm{CH}_{2}\right)$, $7.49(12 \mathrm{H}, \mathrm{s}, \mathrm{Ar}), 7.67(2 \mathrm{H}, \mathrm{d}, J=7.9 \mathrm{~Hz}, \mathrm{Ar}), 7.79(4 \mathrm{H}, \mathrm{m}, \mathrm{Ar}), 8.32(2 \mathrm{H}$, s, Ar). ${ }^{13} \mathrm{C}-\mathrm{NMR}\left(\mathrm{CDCl}_{3}\right) \delta: 29.61\left(\mathrm{CH}_{2}\right), 61.26\left(\mathrm{CH}_{2} \mathrm{~N}\right), 124.02-158.88$ (Ar), 175.30 (CO). FAB-MS $m / z: 749(\mathrm{M}+\mathrm{K})^{+}$. Anal. Calcd for $\mathrm{C}_{44} \mathrm{H}_{32} \mathrm{~K}_{1.5} \mathrm{~N}_{6} \mathrm{O}_{4}: \mathrm{C}, 68.82 ; \mathrm{H}, 4.27 ; \mathrm{N}, 10.94$. Found: C, 69.39, H, 3.99, $\mathrm{N}, 10.71$.

\section{Results and Discussion}

Although $\mathrm{Eu}^{3+}$ is luminescent with the emission wavelength $\left(\lambda_{\mathrm{em}}\right)$ at approximately $615 \mathrm{~nm}$, the luminescence in an aqueous solution is quenched by a water molecule which, being a strong ligand for $\mathrm{Eu}^{3+}$, nonradiatively deactivates the excited ion. For this quenching to be minimized, the suitable ligand should have strong coordination sites for $\mathrm{Eu}^{3+}$ that has variable coordination numbers ( 8 and 9 being most common ${ }^{5)}$ ), as well as an organic structure which absorbs light and effectively transfers its energy to the metal ion. Macrocycle 1 consists of two phenanthroline rings that form an intramolecular cavity with the size of approximately $2.3 \AA$ (by CPK model) which is suitable for the inclusion of $\mathrm{Eu}^{3+}$. The two carboxymethyl groups are attached to strengthen the binding with $\mathrm{Eu}^{3+}$ held in the plane of the ring by coordinating axially; the two phenyl groups are to increase the efficiency of light absorption, and also, in a subsequent study, to provide a site for incorporating a functionality in order for the complex to be covalently linked to proteins.

As outlined in Chart 1, macrocycle 1 was synthesized over 4 steps from dibromide 2 and ditosylate 3 that were readily prepared according to the method described in literature. ${ }^{4)}$ Cyclization of dibromide 2 with ditosylate 3 proceeded smoothly under basic conditions to afford tosylate 4 in excellent yield, which was subjected to detosylation followed by carboxymethylation, ultimately giving ester 6 . Hydrolysis of ester $\mathbf{6}$ with potassium hydroxide gave macrocycle $\mathbf{1}$ as a potassium salt. Upon the addition of $\mathrm{Eu}^{3+}$ to macrocycle 1 in a neutral buffer, a strong fluorescence from $\mathrm{Eu}^{3+}$ with $\lambda_{\mathrm{em}}$ at $619 \mathrm{~nm}$ emerged, whereas the absorption intensity of macrocycle $1\left(\varepsilon=37100\right.$ at $\left.\lambda_{\max }=278 \mathrm{~nm}\right)$ slightly increased $\left(\varepsilon=44200\right.$ at $\left.\lambda_{\max }=279 \mathrm{~nm}\right)$. In contrast to BCPDA, the complex formation appears to be slow, taking account of the observation that it takes approximately $1 \mathrm{~h}$ for the fluorescence intensity to reach its maximum when equivalents of $\mathrm{Eu}^{3+}$ and macrocycle 1 are incubated at $22^{\circ} \mathrm{C}$. Inclusion of $\mathrm{Eu}^{3+}$ by this ligand was also evidenced by FAB-MS measurement, in which a peak corresponding to a monocation of the $1: 1$ complex of $\mathrm{Eu}^{3+}$-macrocycle $1\left(m / z=861[\mathrm{M}-2 \mathrm{H}+\mathrm{Eu}]^{+}\right)$was observed.

Fluorescence measurements of macrocycle 1 were then carried out at $\mathrm{pH} 7.5$ with $\mathrm{Eu}^{3+}, \mathrm{Tb}^{3+}$ and $\mathrm{Sm}^{3+}$, respectively, as potentially usable probes for TR-FIA (Fig. 1). The $\mathrm{Eu}^{3+}$ complex presents sharp emissions at 619 and $594 \mathrm{~nm}$ which originate from the ${ }^{5} \mathrm{D}_{0} \rightarrow{ }^{7} \mathrm{~F}_{1}$ and ${ }^{5} \mathrm{D}_{0} \rightarrow{ }^{7} \mathrm{~F}_{0}$ transitions of $\mathrm{Eu}^{3+}$, respectively; the $\mathrm{Tb}^{3+}$ complex luminesces at $548 \mathrm{~nm}$ due to the ${ }^{5} \mathrm{D}_{4} \rightarrow{ }^{7} \mathrm{~F}_{5}$ transition. ${ }^{5)}$ It is known that the de-activation process of a complex consists of a singlet-triplet intersystem crossing of the ligand molecule and a subsequent energy transfer from the triplet state to the excited $4 f$ level of the metal ion. ${ }^{5)}$ Thus, the fact that neither $\mathrm{Tb}^{3+}$ nor $\mathrm{Sm}^{3+}$ complex exhibits a substantial fluorescence indicates that an effi- 


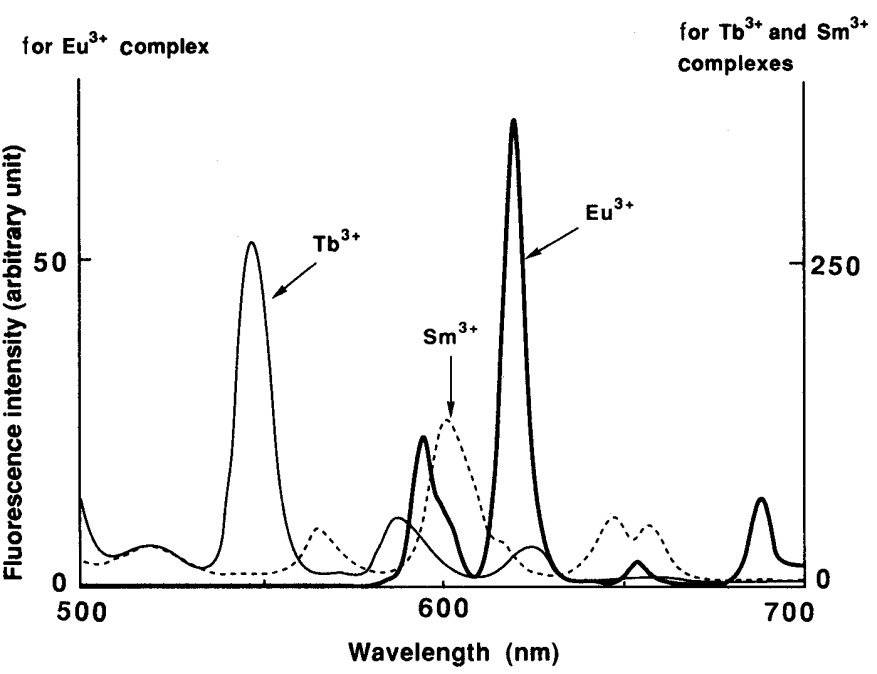

Fig. 1. Fluorescence Spectra of Macrocycle 1 with Lanthanide Ions in $50 \mathrm{~mm}$ Acetate Buffer at $\mathrm{pH} 7.5$

Concentrations of macrocycle 1 and lanthanide ions were $1 \times 10^{-6}$ and $1 \times 10^{-5} \mathrm{M}$, respectively.

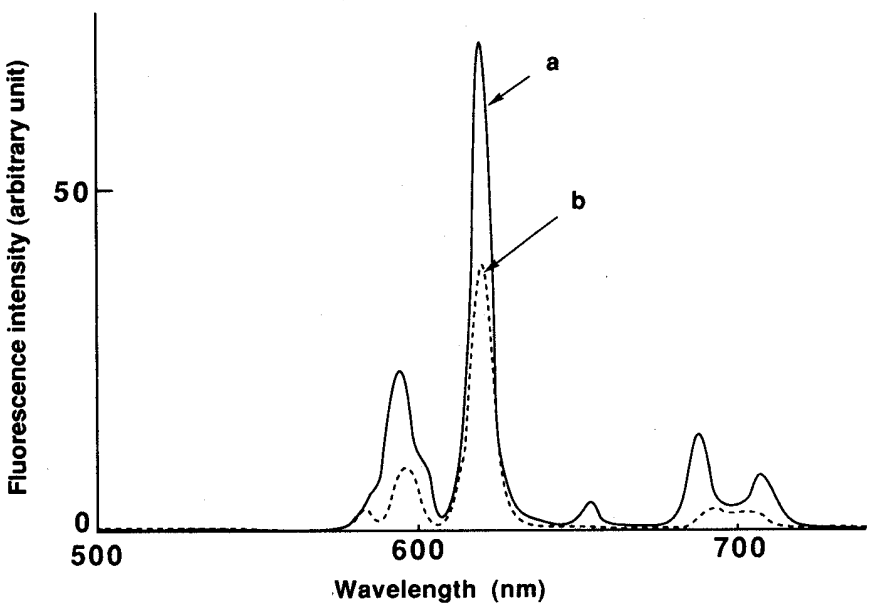

Fig. 2. Fluorescence Spectra of Macrocycle 1 and 4,7-Diphenyl-1,10 phenanthroline-2,9-dicarboxylic Acid in the Presence of $\mathrm{Eu}^{3+}$ in $50 \mathrm{mM}$ Acetate Buffer at $\mathrm{pH} 7.5$

Concentration of $\mathrm{Eu}^{3+}$ was $1 \times 10^{-5} \mathrm{M}$. a: macrocycle $1\left(1 \times 10^{-6} \mathrm{M}\right) ;$ b: 4,7 diphenyl-1,10-phenanthroline-2,9-dicarboxylic acid $\left(1 \times 10^{-6} \mathrm{M}\right)$.

cient intramolecular energy transfer from the triplet excited state of the ligand to the $4 f$ level of the metal ion is most probable with $\mathrm{Eu}^{3+}$.

Figure 2 compares the fluorescence intensity of macrocycle 1 with that of 4,7-diphenyl-1,10-phenanthroline-2,9dicarboxylic acid, a BCPDA derivative which bears two hydrogens instead of two chlorosulfonyl groups, under identical conditions of $\mathrm{pH} 7.5$. The $\mathrm{Eu}^{3+}$-macrocycle 1 complex fluorescence at $619 \mathrm{~nm}$ with the emission intensity being twice as large as that of the BCPDA derivative and, in addition, a larger Stokes shift $(329 \mathrm{~nm}$ compared to $276 \mathrm{~nm}$ of BCPDA).

We next examined an effect of $\mathrm{pH}$ and of detergents in order to maximize the emission intensity of the complex. As shown in the $\mathrm{pH}$ profile in Fig. 3, the emission intensity depends on the type of buffer used, but the maximum intensity is obtained at $\mathrm{pH} \mathrm{5-6.} \mathrm{It} \mathrm{may} \mathrm{be} \mathrm{reasoned} \mathrm{that}$ at acidic $\mathrm{pHs}$ where the carboxy groups are protonated, the chelate formation is sluggish, and at alkaline $\mathrm{pHs}$ an

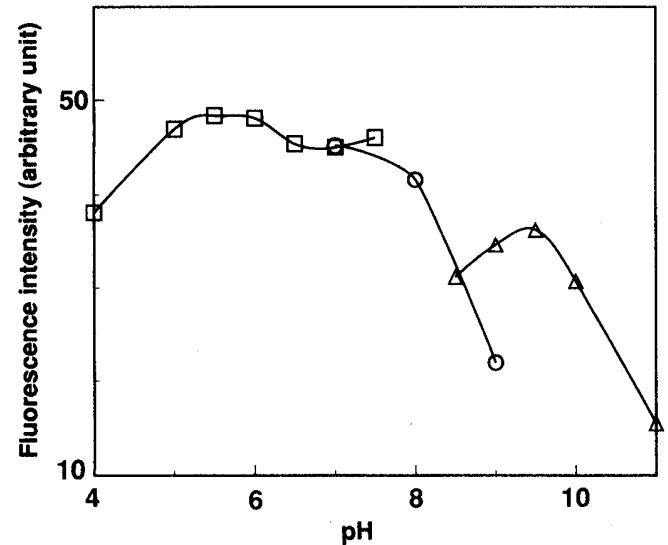

Fig. 3. $\mathrm{pH}$ Profile of the Fluorescence of Macrocycle 1 with $\mathrm{Eu}^{3+}$

Emission wavelength was $619 \mathrm{~nm}$. Concentrations of macrocycle 1 and $\mathrm{Eu}^{3+}$ were both $1 \times 10^{-5} \mathrm{M}$. ( $\left.\square\right) 50 \mathrm{~mm}$ acetate buffer; (O) $50 \mathrm{~mm}$ Tris-acetic acid buffer; $(\triangle)$ $50 \mathrm{~mm}$ carbonate buffer.

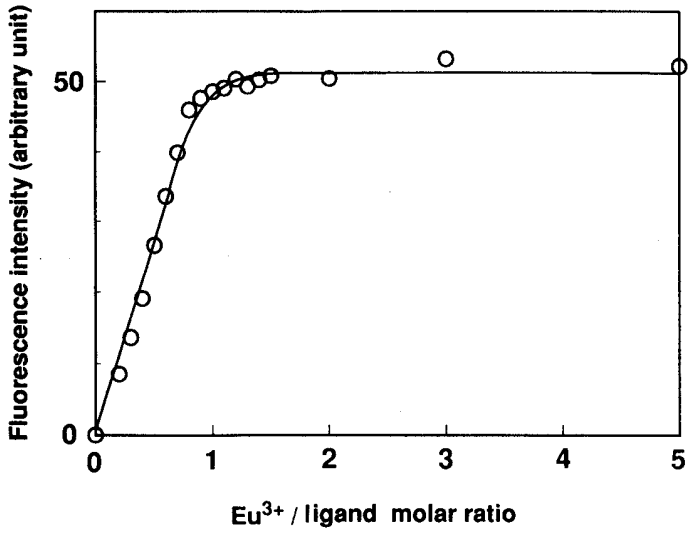

Fig. 4. Emission Intensity at Various Molar Ratios of $\mathrm{Eu}^{3+}-$ Macrocycle 1 Complex in $50 \mathrm{~mm}$ Acetate Buffer at $\mathrm{pH} 7.5$

Concentration of 1 was $5 \times 10^{-6} \mathrm{M}$.

insoluble hydroxide formation becomes predominant. The $\mathrm{pH}$ profile reflects the rate of the complex formation rather than the thermodynamic stability of the complex. Several types of detergents were examined in the hope of increasing the fluorescence by suppressing the aqueous quenching through a micelle formation. Both nonionic and cationic detergents were found to markedly enhance the emission intensity of the $\mathrm{Eu}^{3+}$-macrocycle 1 complex. For example, 13-fold enhancement with Tween 80 and 10-fold with cetyltrimethylammonium chloride were observed in $50 \mathrm{~mm}$ acetate buffer at $\mathrm{pH} 6.0$ with the concentration of the detergents being $3 \%(\mathrm{w} / \mathrm{v})$, whereas no significant enhancement was observed with anionic detergents such as sodium dodecylsulfate under the same conditions.

The composition of the complex was investigated by varying the molar ratio of $\mathrm{Eu}^{3+} /$ macrocycle 1 (Fig. 4). As expected, the complex proved to be $1: 1 \mathrm{Eu}^{3+}$ to macrocycle 1 based on the observation that the emission intensity became constant when the ratio reached 1.0. Moreover, Fig. 4 demonstrates that, in the presence of excess macrocycle 1, there are no complex formations of $\mathrm{Eu}^{3+}$ with more than 1 equiv. of the ligand molecule, which is the case in BCPDA. Once the complex is formed under these conditions, the emission intensity is not reduced even by the addition of a 100-fold molar excess of EDTA, whereas a drastic decrease 
TABLE I. Comparison of Lifetimes and Relative Intensities of the Fluorescences from Eu(III) Complexes ${ }^{a)}$

\begin{tabular}{lcc}
\hline \hline \multicolumn{1}{c}{ Ligand } & $\begin{array}{c}\text { Fluorescence } \\
\text { lifetime }(\mu \mathrm{s})\end{array}$ & $\begin{array}{c}\text { Relative } \\
\text { intensity }^{b)}\end{array}$ \\
\hline Macrocycle 1 & 1144 & 0.64 \\
BCPDA & $400-760^{\text {c) }}$ & 0.33 \\
NTFA/dodecane & $670^{d)}$ & - \\
NTFA/water-TOPO-Triton X-100 & $905^{d)}$ & - \\
\hline
\end{tabular}

a) $[$ Ligand $] /\left[\mathrm{Eu}^{3+}\right]=1 \times 10^{-5} / 1 \times 10^{-4} \mathrm{M} . \quad$ b) The fluorescence intensity of quinine sulfate $\left(1 \times 10^{-5} \mathrm{M}\right.$ in water) was taken as $\left.1.00 . c\right)$ Ref. $\left.3 . d\right)$ Ref. 6 .

can be observed in the case of BCPDA by adding more than a 2-fold excess of EDTA. This implies that the $1: 1$ $\mathrm{Eu}^{3+}$-macrocycle 1 complex is kinetically more inert than BCPDA with a higher stability constant.

The fluorescence lifetime of the $\mathrm{Eu}^{3+}$-macrocycle 1 complex was measured by the pulse technique and the results were compared with those of BCPDA and $\beta$-diketone ligand described in the literatures ${ }^{3,6}$ (Table I). NTFA is the second chelator currently employed in the first approach (vide supra). After pulsed excitation, the decay of the fluorescence of the complex in $50 \mathrm{~mm}$ acetate buffer at $\mathrm{pH} 6.0$ followed the first order kinetics, which gave a longer lifetime of $1144 \mu$ s than those reported for BCPDA. This longer lifetime may be attributed to a better shielding of $\mathrm{Eu}^{3+}$ from bulk water by the macrocyclic ligand. Since a lifetime of an $\mathrm{Eu}^{3+}$ complex is mainly determined by the rate of radiative emission from the excited level of $\mathrm{Eu}^{3+}$ and accordingly by the rate of radiationless de-activation via an energy transfer to the surrounding molecule, it is very sensitive to the chemical nature of the ligand environment. ${ }^{5)}$ It is therefore reasonable to assume that macrocycle 1 has a lesser number of water molecules in its inner coordination site than does BCPDA.

In summary, a new chelator, macrocycle 1, was synthesized and demonstrated to form a stable $1: 1$ complex with $\mathrm{Eu}^{3+}$ which has a higher fluorescence intensity and a longer fluorescence lifetime than that of BCPDA, and these are favorable when used as a label in TR-FIA applications. Introducing a functionality to macrocycle 1 to be covalently linked to a macromolecule is currently being undertaken.

Acknowledgements The authors are grateful to Dr. Ken'yu Kina and Dr. Ichiro Murase of Dojindo Laboratories for their helpful discussions and comments, and to Mr. Hiroshi Sato, Miss Eiko Nakajima, Miss Yasuko Shimizu and Miss Yuki Tomita of Mochida Pharmaceutical Co., Ltd. for their technical assistance.

\section{References}

1) I. Hemmilä, S. Dakubu, V. M. Mukkala, H. Siitari and T. Lövgren, Anal. Biochem., 137, 335 (1984); I. Hemmilä, Clin. Chem., 31, 359 (1985).

2) E. P. Diamandis, Clin. Biochem., 21, 139 (1988); E. P. Diamandis, R. C. Morton, E. Reichstein and M. J. Khosravi, Anal. Chem., 61, 48 (1989); E. P. Diamandis and T. K. Christopoulos, ibid., 62, 1149A (1990); R. C. Morton and E. P. Diamandis, ibid., 62, 1841 (1990).

3) R. A. Evangelista, A. Pollak, B. Allore, E. F. Templeton, R. C. Morton and E. P. Diamandis, Clin. Biochem., 21, 173 (1988).

4) C. J. Chandler, L. W. Deady and J. A. Reiss, J. Heterocycl. Chem., 18, 599 (1981)

5) F. S. Richardson, Chem. Rev., 82, 541 (1982).

6) M. Morin, R. Bador and H. Dechaud, Anal. Chim. Acta, 219, 67 (1989). 